ISSN: 2224-0616

Int. J. Agril. Res. Innov. Tech. 10(1): 13-21, June 2020

DOI: https://doi.org/10.3329/ijarit.v10i1.48089
OPEN OCASES

Available online at https://ijarit.webs.com https://www.banglajol.info/index.php/IJARIT

\title{
Effects of water stress applied at different phenological phases of chickpea (Cicer arietinum L.)
}

\author{
L. Mekonnen \\ Received 07January 2020, Revised 13 April 2020, Accepted 20 June 2020, Published online 30 June 2020
}

\begin{abstract}
A B S T R A C T
A pot experiment was conducted to evaluate the response of two chickpea varieties to water stress at the College of Agriculture campus, Hawassa University under greenhouse from January to June 2017. Three water stress levels i.e. without stress (control), vegetative water stress and seed filling water stress were assigned as main plot, chickpea varieties Habru (Kabuli type) and Mastewal (Desi type). The treatments were laid in split plot design with four replications. The results showed that water stress significantly affected all parameters studied in this experiment. The seed filling water stress resulted greater reductions in the value of all tested parameters studied compared to optimum watering and vegetative stress except number of primary branches and harvesting index, which were significantly lower under vegetative water stress. As well, the two varieties significantly differed for all observed parameters except number of nodules per plant and nodule dry weight. Days to flowering, pod maturity, number of pods per plant, number of seeds per pod and harvest index were significantly higher for Mastewal variety while, plant height, number of primary branches, number of secondary branches, dry biomass, seed yield per plant, hundred seed weight and root dry weight were greater for Habru variety. Days to flowering, plant height, seed yield per plant, hundred seed weight, number of pods per plant and harvest index were significantly affected $(\mathrm{p}<0.05)$ due to all two way interactions. Water management schemes that ensure to avoid especially terminal water stress could help to maintain chickpea production, which is usually grown with residual moisture by the majority of Ethiopian farmers. Given the fact that the results are obtained from a pot experiment there is a need to substantiate the findings with field experiments conducted under contrasting moisture environments.
\end{abstract}

Keywords: Chickpea type, Water deficit, Drought stress.

Worabe Agricultural Research Center, South Agricultural Research Institute, Silti Shewa, Worabe, Ethiopia.

*Corresponding author’s email: lakemekonnen@gmail.com (L. Mekonnen)

Cite this article as: Mekonnen, L. 2020. Effects of water stress applied at different phenological phases of chickpea (Cicer arietinum L.). Int. J. Agril. Res. Innov. Tech. 10(1): 13-21. https://doi.org/10.3329/ijarit.v10i1.48089

\section{Introduction}

Drought stress, absence of appropriate fertilizer use and limited application of other recommended crop production packages of chickpea are the main contributors for low yield. Therefore, there is an opportunity to increase chickpea productivity per unit area in the region through introduction of appropriate and affordable technologies that include appropriate fertilizer formulations, inoculation and identification of relatively better yielding varieties (Kabuli and Desi) under water stress conditions. Water deficit is a major constraint, which reduces the productivity of crops. It is known that chickpea thrives well under drought conditions. However, there is a greater variability in yield performances of different chickpea genotypes under water stress. Attempts to measure the degree of tolerance with a single parameter are limited because of the multiplicity of the factors and their interactive contribution to drought tolerance under field conditions (Paramesh and Salimath, 2008).

In the Southern Ethiopia, chickpea is sown as a double crop in early September after harvesting the principal crops. As a result, chickpea is essentially grown on residual soil water, which often exposes the crop to terminal drought and soil nutrient deficiency during its active growth period (Anbessa and Bejiga, 2002).

Water deficit during late vegetative and reproductive stages is one of the limiting factors for production of this crop in the region. The

International Journal of Agricultural Research Innovation \& Technology An open access article under (C) () 
severity of water stress varies from year to year, depending on the amount and distribution of rainfall. Supplementary irrigations at critical stages of crop growth and development can improve chickpea yield substantially (Soltani et al., 2001). However, this requires knowledge on the relative sensitivity and associated yield penalties on the crop when exposed to drought at different phases. Chickpea yields are low in the Southern Ethiopia especially in Meskan district. It is essential to generate adequate information by studying the response of chickpea types to water deficit in order to understand and prepare optimum agronomic packages. Therefore, this study was initiated with the following objectives:

- To determine the critical stage of chickpea crop for water stress.

- To study the effects of water deficit on the yield and yield components, and other important agronomic traits of Desi and Kabuli chickpea varieties.

\section{Materials and Methods}

\section{Description of experimental site}

A pot experiment was conducted at Hawassa University, College of Agriculture, SNNPR's, Ethiopia at $07^{\circ} 3^{\prime} \mathrm{N}$ and $038^{\circ} 28^{\prime} \mathrm{E}$, and at 1708 masl. The soil was collected from Meskan district chickpea producing farms. Meskan is one of the districts in Guraghe Zone and located between $7.99-8.28^{\circ} \mathrm{N}$ latitude, $38.26-38.58^{\circ} \mathrm{E}$ longitude and 1501-3500 masl altitude. The area receives annual rainfall of $1062.3 \mathrm{~mm}$ and has average annual temperature of $17 \cdot 4^{\circ} \mathrm{C}$.

\section{Treatments and experimental design}

Treatments comprised of three factors: namely three water stress levels (without stress (control), stress at mid vegetative stage and stress at seed filling stage by withhelding irrigation until total available water arrive at 25\%). Mastewal (Dessi) and Habru (Kabuli) improved chickpea varieties, which were released by DBARC/ARARI in 2006, and DARC/EIAR in 2004, respectively, were used for the study. They are selected because of their high yield, and higher price in export markets. Moreover, these varieties were identified as best performing in the study area through participatory variety selection (Sheleme et al., 2013).

The treatments were arranged in a split-plot design to avoid contamination during watering with four replications, in which water stress treatments were allocated in the main plot, chickpea variety treatments as the sub plots. From four replications, one randomly selected replication was used for root and nodule data collections.
The pots were arranged with a distance of $20 \mathrm{~cm}$ between pots and $40 \mathrm{~cm}$ between blocks. Blocking was done north to south direction in order to avoid radiation gradient, which is a driving force for evapotranspiration. Random soil samples $(0-30 \mathrm{~cm})$ collected by auger from five selected chickpea growing farms were composited. Plastic pots having $24 \mathrm{~cm}$ diameter and $23 \mathrm{~cm}$ height with 10 liters capacity were used. Each pot was filled with $10 \mathrm{~kg}$ of soil. Five seeds of chickpea inoculated with $\mathrm{CP}_{7}$ Rhizobium strain from Holleta Agricultural Research Center at the rate of $0.5 \mathrm{~kg} \mathrm{ha}^{-1}$ were planted in each pot. After germination, seedlings were thinned out to three in each pot. DAP fertilizer was applied by using bottle cork as side band at the double rate of $100 \mathrm{~kg} \mathrm{ha}^{-1}$. Because plants grown in pots meet their nutrient requirement from confined soil mass only, while plants grown in fields draw nutrients from all sides and deeper layers (subsoils) without any barrier or hindrance. So, potted plants need almost double the dose of applied fertilizer nutrients (compared to those grown in fields) for normal growth (Kundu et al., 1996). Therefore, each pot received 1.8 g DAP by calculating on plant basis.

\section{Water management procedures}

All pots were well watered until the beginning of water stress treatments. The water application was done by measuring the soil moisture content using soil moisture meter (Delta-T-Device, Model HH2), which was installed at $12 \mathrm{~cm}$ depth in the pots. The reading was displayed in volumetric water content. For control group soil water in each pot was maintained throughout around field capacity. The amount of water applied was calculated based on water deficit (root zone depletion) as explained by FAO (2012) (Equation 1). Graduated cylinder was used to measure the amount of water applied.

$D r=W r f c-W r t$

Where,

$\mathrm{Dr}=$ root zone depletion $(\mathrm{mm}), \mathrm{Wr}(\mathrm{fc})=$ soil water content of the root zone at field capacity $(\mathrm{mm}), \mathrm{Wr}(\mathrm{t})=$ soil water content of the root zone expressed as depth (mm).

TAW $=1000(f c-p w p) z$

Where,

TAW = total available water (\%), fc = field capacity (\%), pwp (\%) = permanent wilting point and $\mathrm{z}=$ pot height $(\mathrm{cm})$.

One day before starting the treatments, soil moisture in each pot was maintained to field capacity so that the soil moisture at each pot was uniform. When the fourth multifoliate leaf has unfolded from the stem, the irrigation was completely withheld for vegetative stress 
treatments until the moisture content of the soil arrived at $25 \%$ of TAW. It took 16 days to reach $25 \%$ of TAW. Then normal irrigation was applied. When chickpea produce early seed (seed in any single pod fill the pod cavity), water application was withheld for seed filling water stress. To arrive at $25 \%$ of TAW, it took only 14 days.

\section{Measurements and statistical analysis}

Morphological and agronomic data (Plant height $(\mathrm{PH})$, number of primary branches (NPB), number of secondary branches (NSB), dry bio mass (DM)), root and nodule parameters (number of nodules per plant (NNPP), nodule dry weight (NDW) and root dry weight (RDW)) were collected.

Also at harvest, plant yield and yield component data (number of pods per plant (NPPP), number of seeds per pod (NSPP), seed weight per plant (SWPP), hundred seed weight (HSW)) were collected. Harvest index (HI) was calculated as the ratio of seed dry weight to total crop dry weight.

\section{Drought intensity index}

It was computed to compare the severity of stress between vegetative and seed filling stage (Fischer and Maurer, 1978).

$\mathrm{DII}=1-(\mathrm{YsYp})$

Where, DII = drought intensity index, Ys = average yield under water stress condition and Yp $=$ average yield under optimum watering.

\section{Drought resistance index}

It was computed to identify a variety that performed well under stress and normal condition (Hall, 1993).

DRI $=$ Ysi $*(Y s i Y p i) Y s$

Where,

DRI $=$ drought resistance index, Ysi $=$ yield under stress condition, Ypi = yield under optimum condition, Yp = average yield under water stress condition.

\section{Statistical analysis}

The analysis of variance was carried out using statistical packages and procedures appropriate to split plot treatment design using SAS Computer Software. Mean separation was carried out by using least significance difference (LSD) at 5\% probability level.

\section{Results and Discussion}

\section{Weather data}

Daily maximum and minimum air temperatures ranged between $37.64^{\circ} \mathrm{C}$ and $14.75^{\circ} \mathrm{C}$, respectively (Fig.1). During flowering stage, average daily temperature was relatively high. As a result, number of pods per plant was reduced due to flower abortion by high temperature.

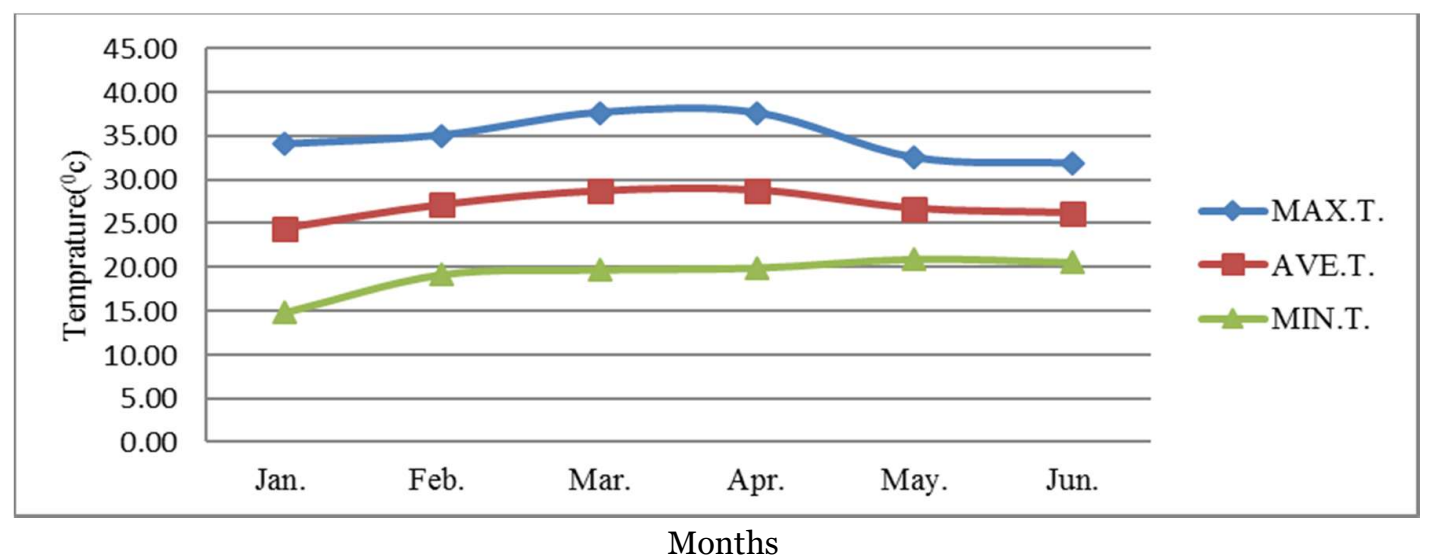

Fig. 1. Monthly mean minimum and maximum temperature $\left({ }^{\circ} \mathrm{C}\right)$ data of the greenhouse.

MAX.T. = maximum temperature $;$ MIN.T. = minimum temperature and AVE.T. = average temperature. The crop growth period was January to June 2017.

\section{Phenological parameters}

Both water stress and variety had statistically significant $(\mathrm{p}<0.05)$ effect on days to flowering and pod maturity in chickpea. Vegetative water stress significantly increased ( 54 days) the days to flowering compared to optimum watering (37 days) (Table 1). Delayed in days to flowering with water stress at vegetative stage might be due to absence of enough water for cell differentiation at the shoot apical meristem. This is in agreement with Saxena et al. (1993) who reported that abiotic stress, particularly drought and thermal, delay the chickpea flowering phase. Hughes et al. (1987) also suggested that the exposure of the culture to water stress shortens its biological cycle and delays its flowering. 
Relatively early pod maturity (98 days) was recorded in plants under seed filling stress compared to optimum water application (110 days) and vegetative stress (112 days) (Table 1). This result is in agreement with that of Kamel et al. (2012) who found that vegetative water stress significantly delays days to pod maturity as compared to optimum water applications. Longer period to flowering and to pod maturity was recorded in the Desi (Mastewal) chickpea compared to Kabuli (Habru) (Table 1). The results are supported by the results of Sheleme et al. (2013) who reported that the time to both flowering and pod maturity in Mastewal was longer than Habru.

Table 1. Main effects of water stress and variety on some phenological and growth parameters of chickpea.

\begin{tabular}{|c|c|c|c|c|c|c|}
\hline Treatments & $\begin{array}{l}\text { DTF } \\
\text { (days) }\end{array}$ & $\begin{array}{l}\text { DPM } \\
\text { (days) }\end{array}$ & $\begin{array}{l}\mathrm{PH} \\
(\mathrm{cm})\end{array}$ & NPB & NSB & $\begin{array}{l}\text { DBM } \\
\left.\text { (g plant }^{-1}\right)\end{array}$ \\
\hline \multicolumn{7}{|l|}{ Stress } \\
\hline OPT & $37.23 \mathrm{~b}$ & $110.26 \mathrm{~b}$ & $44.23 a$ & $5.43 a$ & $6.13 a$ & $31.02 \mathrm{a}$ \\
\hline VS & $54.23 a$ & $112.33 a$ & $39.56 b$ & $3.96 c$ & $4.03 \mathrm{~b}$ & $25.69 b$ \\
\hline SFS & ----- & $97.90 \mathrm{c}$ & $39.80 b$ & $4.30 b$ & $4.56 \mathrm{~b}$ & $20.00 c$ \\
\hline $\operatorname{LSD}_{(0.05)}$ & 0.38 & 0.70 & 0.64 & 0.32 & 0.54 & 0.70 \\
\hline CV (\%) & 26.11 & 13.81 & 5.36 & 11.66 & 58.52 & 3.46 \\
\hline \multicolumn{7}{|l|}{ Variety } \\
\hline MAS & $49.03 a$ & $111.71 a$ & $37.93 \mathrm{~b}$ & $4.04 \mathrm{~b}$ & $4.68 \mathrm{~b}$ & $23.55 \mathrm{~b}$ \\
\hline $\mathrm{HAB}$ & $42.43 \mathrm{~b}$ & $101.95 \mathrm{~b}$ & $44.46 a$ & $5.08 \mathrm{a}$ & $5.13 a$ & $27.59 a$ \\
\hline $\mathrm{LSD}_{(0.05)}$ & 0.31 & 0.57 & 0.52 & 0.26 & 0.44 & 0.57 \\
\hline CV (\%) & 21.88 & 21.08 & 4.13 & 17.43 & 19.67 & 9.27 \\
\hline
\end{tabular}

Means with the same letters are not significantly different; LSD = Least significance difference; DTF = days to flowering; $D P M=$ pod maturity; $P H=$ plant height; $N P B=$ number of primary branch; $N S B=$ number of secondary branch.

In combinations of water stress with variety the longest duration (56 days) of flowering was observed in Mastewal variety with vegetative stress. However, the shortest duration (32 days) was observed in Habru variety with optimum watering.

\section{Growth parameters}

Plant height, primary and secondary branches were significantly affected by the main effects of water stress and variety as well as their two way interactions. Mastewal was significantly shorter in plant height and minimum in both primary and secondary branches than Habru (Table 1). And also both vegetative and seed filling water stress treatments significantly reduced plant height in Habru and Mastewal variety. This might be due to decrease in cell division and cell enlargement under water stress (Manivannan et al., 2007). In agreement with this, Yaqoob et al. (2012) suggested that moisture stress at vegetative stage being harmful and detrimental in the most critical stage for screening chickpea germplasm under drought prone conditions. Shamsi et al. (2010) also found that vegetative water stress in chickpea reduced plant height and branch productions significantly. Similar result was given in soybean (Mustapha et al., 2014).

\section{Dry Biomass}

Results of the analysis of variance revealed that water stress had significant effect on above ground dry weights of the plants. Optimum water application treatment significantly increased dry biomass per plant (31.02 g) as compared to both vegetative (25.69 $\mathrm{g}$ ) and seed filling water stress treatments (20.01) (Table 1). This is in agreement with the results reported by Bakhsh et al. (2007) where $36 \%$ increase in total dry weight was obtained due to irrigation. The dry biomass reduction in water stressed pots could be attributed to lower $\mathrm{CO}_{2}$ accumulation in biochemical reactions of photosynthesis and therefore to lower carbohydrates production (Hopkins and Huners, 2009; Pots et al., 2008).

Similarly, significant $(\mathrm{p}<0.05)$ variation was observed due to differences between chickpea varieties. Habru variety resulted in the highest dry biomass (27.59 g), while lower amount (23.55 g) was recorded from Mastewal (Table 1). This is in agreement with Randhawa et al. (2014) who reported that there is genotypic variation in chickpea dry matter production.

\section{Yield and yield components of chickpea}

Results of the analysis of variance for number of pods per plant, seed yield per plant, hundred seed weight revealed that the main effects of water stress and variety as well as their interaction were significant. 
Optimum water application produced significantly the highest number of pods per plant, while lowest number of pods per plant was observed under seed-filling water stress (Table 2). This is in agreement with Cyrus et al. (2011) reported that optimum watering treatment had the highest (40) number of pods per plant and the severe water stress treatment had the lowest number of pods per plant (12). Similarly, Alla et al. (2015) showed significantly ( $\mathrm{p} \leq$ 0.001) decreasing number of pods per plant with the increase in water deficit. Shaban et al. (2012) and Gwathmey and Hall (1992) reported similar results. The significant reduction in number of harvested pods per plant under drought stress might be attributed to the abscission of the reproductive structures.

Table 2. Main effects of water stress and variety on yield and yield components of chickpea.

\begin{tabular}{|llllll|}
\hline Treatments & NPPP & $\begin{array}{l}\text { SYPP } \\
(\mathrm{g})\end{array}$ & HI & $\begin{array}{l}\text { HSW } \\
(\mathrm{g})\end{array}$ & NSPP \\
\hline Stress & & & & & \\
\hline OPT & $43.73 \mathrm{a}$ & $10.57 \mathrm{a}$ & $0.342 \mathrm{~b}$ & $20.37 \mathrm{a}$ & $1.35 \mathrm{a}$ \\
\hline VS & $39.1 \mathrm{~b}$ & $8.33 \mathrm{~b}$ & $0.328 \mathrm{c}$ & $16.90 \mathrm{~b}$ & $1.18 \mathrm{~b}$ \\
\hline SFS & $35.73 \mathrm{c}$ & $7.06 \mathrm{c}$ & $0.358 \mathrm{a}$ & $12.23 \mathrm{c}$ & $1.26 \mathrm{~b}$ \\
\hline LSD (0.05) & 0.78 & 0.22 & 0.0093 & 0.33 & 0.10 \\
\hline CV (\%) & 4.08 & 7.89 & 6.66 & 5.79 & 12.06 \\
\hline Variety & & & & & \\
\hline MAS & $41.66 \mathrm{a}$ & $8.36 \mathrm{~b}$ & $0.358 \mathrm{a}$ & $14.89 \mathrm{~b}$ & $1.44 \mathrm{a}$ \\
\hline HAB & $37.37 \mathrm{~b}$ & $8.94 \mathrm{a}$ & $0.326 \mathrm{~b}$ & $18.11 \mathrm{a}$ & $1.09 \mathrm{~b}$ \\
\hline LSD (0.05) & 0.64 & 0.18 & 0.0076 & 0.27 & 0.08 \\
\hline CV (\%) & 3.94 & 4.43 & 5.26 & 3.81 & 8.49 \\
\hline
\end{tabular}

Means with the same letters are not significantly different; $L S D=$ Least significance difference; DTF $=$ days to flowering; $D P M=$ pod maturity; $P H=$ plant height; $N P B=$ number of primary branch; $N S B=$ number of secondary branch.

The number of pods per plant in the Mastewal variety was $10.29 \%$ more than that of Habru variety (Table 2) indicating the varietal differences in producing pods. This is in line with the report of Sheleme et al. (2013) which indicated that number of pod per plant in the Mastewal variety produced $21.32 \%$ higher over Habru variety.

In the interaction effects of water stress with variety, Mastewal with optimum watering produced the maximum number of pods per plant, while Habru and Mastewal with vegetative water stress produced smaller number of pods per plant. Similar result was reported by Shaban et al. (2012).

The results showed that under non water-stressed conditions chickpea varieties significantly gave better seed yield than under water-stressed conditions of both stages. For instance, the lowest seed yield per plant (10.26 g) was recorded from seed filling water stress. It decreases the seed yield per plant by $38.85 \%$ and $23.66 \%$ compared to optimum water applications and vegetative water stress respectively (Table 2). The current study is in agreement with Leport et al. (1999) who reported that water stress during flowering and grain filling caused $50-80 \%$ reductions in grain yield due to restrictions in photosynthesis. Chickpea is more sensitive to water stress during reproductive stages and consequently experiences substantial yield loss (Turner et al., 2001; Nayyar et al., 2005). Ghassemi- Golezani et al. (2012) also reported that drought stress at grain filling stage reduced grain yield by up to $50 \%$ in chickpea. Reduction in grain number was due to a decrease in pod formation and an increase in pod abortion (Fang et al., 2009; Ghassemi-Golezani et al., 2012). Withholding water applications at pod filling stage can decrease grain filling duration (Ghassemi-Golezani et al., 2009) and photosynthate mobilization to grains, thereby decreasing grain weight (Sadeghipour, 2008).

Decreasing seed yield per plant due to water deficit was attributed to reductions in pod number per plant, dry biomass and 100 seed weight. These results confirm previous field studies with chickpea where by water deficit reduces biological and grain yields (GhassemiGolezani et al., 2009; Bahavar et al., 2009; NiariKhamssi et al., 2010).

In the main effects of variety, Habru was the highest seed yielding compared to Mastewal (Table 2). Although Mastewal produced more number of seed per plant, its seed size was very small compared to Habru variety, which has heavier seeds. Due to this reason, Habru gave the highest seed yield per plant (8.94 g) (Table 2).

In the interaction effects of water stress and variety, the highest seed yield per plant was obtained from Mastewal variety with optimum watering though the differences was not significant with Habru variety under optimum watering. The lowest seed yield per plant was obtained from Mastewal variety with seed filling water stress (Fig. 2). This is in line with Shaban et al. (2012) who reported performance variation between genotypes when exposed to different levels of moisture availability. 


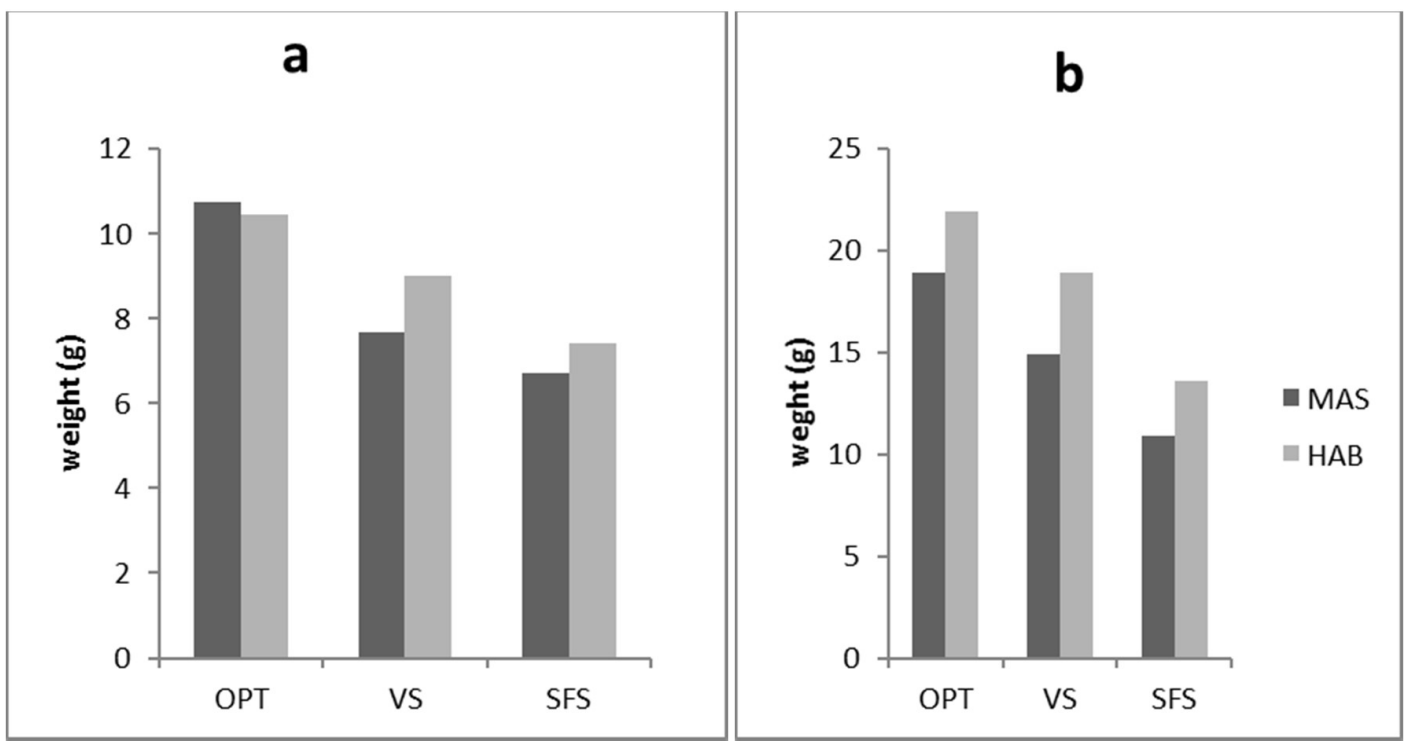

Fig. 2. The interaction effects of water stress and variety on seed yield per plant and hundred seed weight in gram. $\mathrm{a}=$ seed yield per plant and $\mathrm{b}=$ hundred seed weight.

Hundred seed weight was significantly affected by the main effects of water stress. It was reduced due to seed filling water stress and vegetative water stress by $40 \%$ and $17 \%$, respectively compared to optimum watering (Table 2). This is in agreement with Singh and Kuhad (2005) who reported that water stress resulted in significant reduction of test weight (100-seed weight) of chickpea. Decrease in hundred seed weight under stress conditions might be due to lower photosynthetic translocation in the developing grain. However, the weight was least affected when stress was applied at the vegetative stage.

Similarly, hundred seed weight in chickpea was significantly different due to main effects of variety. The highest value of hundred seed weight was obtained from Habru variety (18.11g) compared to Mastewal (14.89 g) (Table 2). This is in line with Sheleme et al., (2013) who reported that Habru is higher in seed yield than Mastewal variety.

Interaction effects of water stress and variety significantly $(\mathrm{p}<0.05)$ affected hundred seed weight. Habru variety with optimum watering gave the highest hundred seed weight, while Mastewal variety with seed filling water stress gave the lowest hundred seed weight (Fig. 2).

The result of analysis of variance for number of seeds per pod showed significant on main effects of water stress, variety and fertilizer formulation. Number of seeds per pod was significantly highest with optimum water application than with both vegetative and seed filling stress conditions (Table 2). In line with this, Mansourifar et al. (2011) showed that moderate water stress significantly reduced number of seeds per pod compared to no water stress. The reduction in number of grains per pod under drought stress treatments might be attributed to the limitation of dry matter partitioning to the reproductive sink or even grain formation factors as reported by Turk and Hall (1980). However, Kazem et al. (2013) reported that environmental factors had little effect on grains per pod and it is mainly influenced by genotype.

Similarly, analysis of variance revealed that number of seeds per plant was significantly $(p<0.05)$ affected by variety. Mastewal variety produced significantly greater number of seeds per pod than Habru (Table 2). Mar (2011) also reported that PCHL 04-5 (Desi) showed the highest number of seeds per pod (2) followed by ICCV 03111 (Desi) and Yezin 4 (Desi), while the lowest value (1.0) was recorded in PCHL 04-32 (Kabuli). Significant variability in seeds per pod in chickpea is also observed by Ahmad et al. (2003).

The result of analysis of variance for harvesting index showed significant variation due to main effects of water stress. The highest value of harvest index was obtained from seed filling stress, while significantly lowest value was recorded with vegetative stress (Table 2). Contrary to this, Mansourifar et al. (2011) reported that no water stress has the highest harvest index and severe water stress has the lowest harvest index. The reduction of harvest index with seed filling water stress could be attributed to the loss of leaves following severe senescence following the water stress.

Analysis of variance revealed that harvest index was significantly $(\mathrm{p}<0.05)$ affected by varieties. The higher harvest index (35.8\%) belonged to Mastewal compared to Habru (32.6\%) (Table 2). Similar results were reported by Mansur et al. (2010) and Arya and Khuswaha (2000) in chickpea. 
Significant $(\mathrm{p}<0.05)$ difference was observed due to the interaction effects of water stress and variety on harvest index. Highest value of harvest index (0.37) was found from Mastewal variety with optimum watering and seed filling stage water stress. Minimum value of harvest index (o.31) was obtained from Habru under optimum watering (Table 2).

\section{Drought intensity index}

Drought intensity index was calculated to quantify the severity of drought stress at both vegetative and seed filling stages. Accordingly, the higher value of DII was obtained from pots exposed to water stress at seed filling growth stage (0.32) compared to vegetative water stress (o.22). Minimum value of DII at vegetative stage might be due to availability of more time to make further adjustment in its vegetative growth as well as yield and yield components (Walelign and Skjelvag, 2006). However, water stress during seed filling stage caused relatively higher value of DII since drought stress at this stage causes abortion of flowers and ovules, senescence of flowers and pods, which all have direct relations with yield. According to Fischer and Maurer (1978), DII $\geq 0.7,0.2-0.5$, <0.2 indicated severe, moderate and no stress, respectively. Thus, both vegetative and seed filling water stress level were moderate according to the drought intensity index.

\section{Drought resistance index}

Under vegetative water stress, high DRI value was recorded from Habru (0.93) indicating that they are drought tolerant compared to Mastewal (o.75) variety. Drought stress applied at seed filling stage resulted in high DRI values of Habru (o.66) compared to Mastewal (o.59). Generally, both varieties tolerate water stress exposed at vegetative stage. Accordingly, Habru variety was more resistant to both stress conditions. This was not consistent with the previous observations made regarding performance of the varieties (Sheleme et al., 2013). It indicated that the Desi variety Mastewal performed better under moisture limiting environments compared to the Kabuli Habru. The differences between the findings may be attributed to the variation involved with the nature of the experiments, which was a field experiment in Sheleme et al. (2013).

The results of present study revealed that the main effects of water stress influenced all tested parameters of chickpea. Except harvest index and drought intensity index, which had highest value with seed filling water stress, all growth, yield and yield attributed parameters of chickpea improved due to optimum water application.
Similarly, variety had significant effect $(\mathrm{p}<0.05)$ on all parameters of chickpea except number of nodules per plant and nodule dry weight. Days to flowering, days to pod maturity, number of pods per plant, harvest index and number of seeds per plant were higher with Mastewal variety, while plant height, number of primary and secondary branches, dry biomass, seed yield per plant, hundred seed weight, root dry weight and drought intensity index were higher with Habru variety.

\section{References}

Ahmad, B., Wahid, M.A., Bugti, R.A., Zahid, M.A. and Shaukal, A. 2003. Evaluation of chickpea germplasm for semi-arid zones of Balochistan. Int. J. Agric. Biol. 5: 113-116.

Alla, J.M.K., Ibrahim, O.H. and Adam, H.S. 2015. Yield and water productivity of chickpea (Cicer arietinum L.) as influenced by different irrigation regimes and varieties under semi desert climatic conditions of Sudan. Agril. Sci. 6: 1299-1308. https://doi.org/10.4236/as.2015.611124

Anbessa, Y. and Bejiga, G. 2002. Evaluation of Ethiopian chickpea landraces for tolerance to drought. Gen. Res. Crop Eval. 49: 557564. https://doi.org/10.1023/A:1021210601480

Arya, R.L. and Khuswaha, B.L. 2000. To study the irrigation and phosphorus management in rice chickpea cropping system. pp. 23-37. In: Proc. First Int. Agron. Congress. Eds. Ahlawat, IPS and Surendrasingh. New Delhi, India.

Bahavar, N., Ebadi, A., Tobeh, A. and Jamaati-ESomarin, S. 2009. Effects of mineral nitrogen on water use efficiency of chickpea (Cicer arietinum L.) under water deficit condition. Res. J. Environ. Sci. 3: 332-338. https://doi.org/10.3923/rjes.2009.332.338

Bakhsh, A., Malik, S.R., Aslam, M., Iqbal, U. and Haqqani, A.M. 2007. Response of chickpea genotypes to irrigated and rain-fed conditions. Int. J. Agric. Biol. 9: 590-593.

Cyrus, M., Morad, S., Mokhtar, G. and Abasalt, R. 2011. Effect of drought stress and $\mathrm{N}$ fertilizer on yield, yield components and grain storage proteins in chickpea (Cicer arietinum L.) cultivars. Afr. J. Plant Sci. 5(11): 634-642.

Fang, X., Turner, N.C., Yan, G., Li, F. and Siddique, K.H.M. 2009. Flower numbers, pod production, pollen viability and pistil function are reduced and flower and pod abortion increased in chickpea (Cicer arietinum L.) under terminal drought. $J$. Exp. Bot. 61: 335-45. https://doi.org/10.1093/jxb/erp307

FAO. 2012. Crop-water productivity model to simulate yield response to water. FAO, Rome, Italy, Aqua Crop, version 4, p. 130. Available at link https://wenku.baidu. accessed on December 2017. 
Fischer, R.A. and Maurer, R. 1978. Drought resistance in spring wheat cultivars. Grain yield responses. Aust. J. Agric. Res. 29: 897912. https://doi.org/10.1071/AR9780897

Ghassemi-Golezani, K., Ghanehpoor, S. and Mohammadi-Nasab, A.D. 2009. Effects of water limitation on growth and grain filling of faba bean cultivars. J. Food Agri. Environ. 7: 442-447.

Ghassemi-Golezani, K., Mustafavi, S.H. and Shafagh-Kalvanagh, J. 2012. Field performance of chickpea cultivars in response to irrigation disruption at reproductive stages. Res. Crops. 13: 107-112.

Gwathmey, C.O. and Hall, A.E. 1992. Adaptation to midseason drought of cowpea genotypes with contrasting senescence traits. Crop Sci. 32: $773-778$.

https://doi.org/10.2135/cropsci1992.0011183Xo 03200030039x

Hall, A.E. 1993. Is dehydration tolerance relevant to genotypic differences in leaf senescence and crop adaptation to dry environments? In: Close, T.J. and Bray, E.A. (Eds.) Plant Responses to cellular Dehydration during environmental stress. Current Topics in Plant Physiology, Vol. 10, American Soc. Plant Pathologists, Rockville, Maryland, USA. pp. 1-10.

Hopkins, W.G. and Hüner, N.P.A. 2009. Introduction to Plant Physiology. $4^{\text {th }}$ Edition, John Wiley \& Sons, Inc., Hoboken. 503p.

Hughes, G., Keatinge, J.D.H., Cooper, P.J.M. and Dee, N.F. 1987. Solar-radiation interception and utilization by chickpea (Cicer arietinum L.) Crops in Northern Syria. J. Agric. Sci. 108: 419-424. https://doi.org/10.1017/Soo21859600079454

Kamel, B.M., Boutheina, D. and Abdelhamid, B. 2012. Effects of irrigation on the flowering and maturity of chickpea genotypes, irrigation systems and practices in challenging Environments, Dr. Teang Shui Lee (Ed.). In Tech. 51: 420-429.

Kazem, G., Saeid, G. and Ali, B. 2013. Effects of water supply on field performance of chickpea (Cicer arietinum L.) cultivars. Int. J. Agron. Plant Prod. 4(1): 94-97.

Kundu, D.K., Ladha, J.K. and Lapitande, G.E. 1996. Tillage depth influence on soil nitrogen distribution and availability in a rice lowland. Soil Sci. Soc. Am. J. 60: 11531159.https://doi.org/10.2136/sssaj1996.0361599 $5006000040028 \mathrm{x}$

Leport, L., Turner, N.C., French, R.J., Barr, M.D., Duda, R., Davies, S.L., Tennant, D. and Siddique, K.H. 1999. Physiological responses of chickpea genotypes to terminal drought in a Mediterranean-type environment. Eur. J. Agron. 11: 279-291.

https://doi.org/10.1016/S1161-0301(99)ooo39-8

Manivannan, P., Jaleel, C.A., Klshorekumar, A., Sankar, B., Somasundaram, R., Sridharan,
R. and Panneerselvam, R. 2007. Changes in antioxidant metabolism of (Vigna unguiculata L.) Walp. by Propiconazole under water deficit stress. Colloids Surf. B: Bio interfaces. 57: 69-74.

https://doi.org/10.1016/j.colsurfb.2007.01.004

Mansourifar, C., Shaban, M., Ghobadi, M. and Ajirlu, A.R. 2011. Effect of drought stress and $\mathrm{N}$ fertilizer on yield, yield components and grain storage proteins in chickpea (Cicer arietinum L.) cultivars. Afr. J. Plant Sci. 5(11): 634-642.

Mansur, C.P., Palled. B., Salimath, P.M. and Halikatti, S.I. 2010. An analysis of dry matter production, growth and yield in kabuli chickpea as influenced by dates of sowing and irrigation levels. Karnataka $J$. Agric. Sci. 23: 457-460.

Mar, M. 2011. Evaluation on performance of chickpea (Cicer arietinum L.) genotypes under water stress condition. PhD Thesis. Yezin Agricultural University, Myanmar. $115 \mathrm{p}$.

Mustapha, Y., Biwe, E.R. and Abdullahi, S. 2014. Effects of moisture stress on the growth parameters of soybean genotypes. Discourse J. Agric. Food Sci. 2(5): 142-148.

Nayyar, H., Kaur, S., Smita, K., Singh, J., Dhir, K.K. and Bains, T. 2005. Water stress induced injury to reproductive phase in chickpea: Evaluation of stress sensitivity in wild and cultivated species in relation to abscisic acid and polyamines. J. Agron. Crop. Sci. 191: 450-457. https://doi.org/10.1111/j.1439037X.2005.00184.X

Niari-Khamssi, N., Ghassemi-Golezani, K., Zehtab-Salmasi, S and Najaphy, A. 2010. Effects of gradual water deficit stress on phonological and morphological traits in chickpea (Cicer aritinum L.). J. Agric. Sci. Tech. 4: 95-100.

Paramesh, S.G. and Salimath, P.M. 2008. Field screening of chickpea genotypes for drought resistance. Karnataka J. Agric. Sci. 21(1): 113-114.

Pots, D.L., Stanley. H., Goulden. W. and Suding, K.N. 2008. The impact of invasion and subsequent removal of an exotic Thistle, Cynara cardunculus, on $\mathrm{CO}_{2}$ and $\mathrm{H} 2 \mathrm{O}$ vapor exchange in a Coastal California Grassland. Biol. Invas. 10: 1073-1084. https://doi.org/10.1007/s10530-007-9185-y

Randhawa, N., Kaur, J. and Singh, S. 2014. Growth and yield in chickpea (Cicer arietinum L.) genotypes in response to water stress. Afr. J. Agril. Res. 9(11): 982-992. https://doi.org/10.5897/AJAR2013.7671

Sadeghipour, O. 2008. Effect of withholding irrigation at different growth stages on yield and yield components of mungbean (Vicia radiataL.) varieties. Amer. Eur. J. Agric. Environ. Sci. 4: 590-94. 
Saxena, N., Johansen, P.C., Saxena, M.C. and Silim, S.N. 1993. Breeding for stress tolerance in cool season food legumes. In: K.B. Singh and Saxena, M.C. (Eds.) John Wiley and Sons Chichester, UK. pp. $245-$ 270.

Shaban, M., Lak, M., Hamidvand, Y., Nabaty, E., Khodaei, F., Yarahmadi, M., Mostafa, S., Ghaeed, M. and Rahmati, Z. 2012. Response of chickpea (Cicer arietinum L.) cultivars to integrated application of Zinc nutrient with water stress. Int. J. Agric. Crop Sci. 4(15): 1074-1082.

Shamsi, K., Kbraee, S. and Haghparast, R. 2010. Drought stress mitigation using supplementary irrigation in rain fed chickpea (Cicer arietinum L.) varieties in Kermanshah, Iran. Afr. J. Biotech. 9(27): 4197-4203.

Sheleme, B., Walelign, W., Birhanu, A. and Workina, K. 2013. Participatory chickpea and lentil variety selection. Final Technical Report, Hawassa University, Ethiopia. 15p.

Singh, N. and Kuhad, M.S. 2005. Role of potassium in alleviating the effect of water stress on yield and seed quality in chickpea (Cicer arietinum L.). National Institute of Ecology. 15: 219-225.
Soltani, A., Khooie, F.R., Ghassemi- Golezani, K. and Moghadam, M. 2001. A simulation study of chickpea crop response to limited irrigation in a semiarid environment. Agric. Water Manage. 49: 225-237. https://doi.org/10.1016/So378-3774(oo)o0143-8

Turk, K.J. and Hall, A.E. 1980. Drought adaptation of cowpea. IV: Influence of drought on water use and relation with growth and seed yield. Agron. J. 72: 440448.

https://doi.org/10.2134/agronj1980.0002196200 $7200030007 \mathrm{x}$

Turner, N.C., Wright, G.C. and Siddique, K.H.M. 2001. Adaptation of grain legumes (pulses) to water limited environments. Adv. Agron. 71: 193-231. https://doi.org/10.1016/Soo652113(01)71015-2

Walelign, W. and Skjelvag, O.A. 2006. The effect of different moisture and light regime on productivity, light interception and use efficiency of common bean. SINET Ethiop. $J$. Sci. 29: 95-106. https://doi.org/10.4314/sinet.v29i2.18264

Yaqoob, M., Hollington, P.A. and Gorham, J. 2012. Shoot, root and flowering time studies in chickpea (Cicer arietinum L.) under two moisture regimes. Food Agric. 24(1): 73-78. https://doi.org/10.9755/ejfa.v24i1.10600 